\title{
The use of imatinib in the treatment of inoperable dermatofibrosarcoma protuberans in the area of the shoulder joint
}

\section{Zastosowanie imatinibu w leczeniu nieoperacyjnego dermatofibrosarcoma protuberans zlokalizowanego w okolicy stawu barkowego}

Joanna Huszno, Danuta Starzyczny-Słota, Elżbieta Nowara

Klinika Onkologii Klinicznej i Doświadczalnej, Centrum Onkologii Instytut im. Marii Skłodowskiej-Curie, Gliwice, Poland

Przegl Dermatol 2014, I01, 197-200

DOI: 10.5 | |4/dr.2014.43810

\section{KEY WORDS:}

dermatofibrosarcoma protuberans, tyrosine kinase inhibitor, imatinib.

SŁOWA KLUCZOWE:

dermatofibrosarcoma protuberans, inhibitor kinazy tyrozynowej, imatinib.
ADDRESS FOR CORRESPONDENCE:

Joanna Huszno PhD

Klinika Onkologii Klinicznej

i Doświadczalnej

Centrum Onkologii Instytut

im. Marii Skłodowskiej-Curie

15 Wybrzeże Armii Krajowej St

44-101 Gliwice, Poland

Phone: +48 322788704

E-mail: joahus@wp.pl

\section{ABSTRACT}

Introduction. Dermatofibrosarcoma protuberans (DFSP) is a rare sarcoma of the skin and subcutaneous tissue. The most common clinical problem is its local recurrence. The therapeutic procedure of choice is radical surgery. In the case of inoperable disease, targeted therapy with imatinib, a tyrosine kinase inhibitor, may cause significant reduction of tumor volume and even enable radical surgery.

Objective. We present the effectiveness of imatinib for the treatment of unresectable DFSP localized in the area of the shoulder joint of a 62-year-old woman.

Case report. The patient met the criteria for inclusion in treatment with imatinib. After 3 cycles of treatment, partial regression of the lesions (above 50\%) was observed. Therapy was complicated by hepatological side effects during the sixth cycle. Treatment was continued with a reduced dose when transaminase levels normalized. In a physical examination and imaging studies, further regression was observed. The patient has regained considerable mobility of the shoulder joint. A decision to continue the treatment has been made.

Conclusions. The use of imatinib allowed a clinical benefit to be gained in the form of significant regression of lesions. A very good treatment response and significant improvement in quality of life of the patient were achieved. The patient has been treated with imatinib for 30 months.

\section{STRESZCZENIE}

Wprowadzenie. Dermatofibrosarcoma protuberans (DFSP) jest rzadkim mięsakiem skóry i tkanki podskórnej. Największym problemem klinicznym są jego miejscowe nawroty. Postępowaniem z wyboru jest radykalne wycięcie chirurgiczne. W przypadku zmian nieoperacyjnych celowana terapia za pomocą imatinibu - inhibitora kinazy tyrozynowej, może spowodować istotne zmniejszenie guza i umożliwić jego chirurgiczne usunięcie. Cel pracy. Przedstawienie skuteczności leczenia imatinibem w przypadku nieoperacyjnego DFSP u 62-letniej kobiety zlokalizowanego w okolicy stawu barkowego.

Opis przypadku. Pacjentka spełniała kryteria do włączenia terapii imatinibem. Po 3 cyklach leczenia stwierdzono częściową (> 50-procentową) regresję guza. Terapię skomplikowały zaburzenia wątrobowe, które wystąpiły podczas 6. cyklu. Po uzyskaniu normalizacji pozio- 
mu transaminaz leczenie kontynuowano, podając zmniejszoną dawkę leku. Zarówno za pomocą badania fizykalnego, jak i badań obrazowych stwierdzono dalsze zmniejszanie masy guza. Pacjentka odzyskała znaczną ruchomość stawu barkowego. Podjęto decyzję o kontynuowaniu terapii.

Wnioski. Zastosowanie imatinibu dało kliniczną korzyść w postaci istotnego zmniejszenia masy guza. Osiągnięto bardzo dobrą odpowiedź terapeutyczną i znaczną poprawę jakości życia chorej. Leczenie imatinibem kontynuowano przez 30 miesięcy.

\section{INTRODUCTION}

Dermatofibrosarcoma protuberans (DFSP) is a rare sarcoma of the skin and subcutaneous tissue. The annual incidence of DFSP is $0.8-4.2$ cases per million people. It occurs mainly in adults (usually between the age of 20 and 40), with equal frequency in both sexes. DFSP is a locally aggressive tumor with a ten-

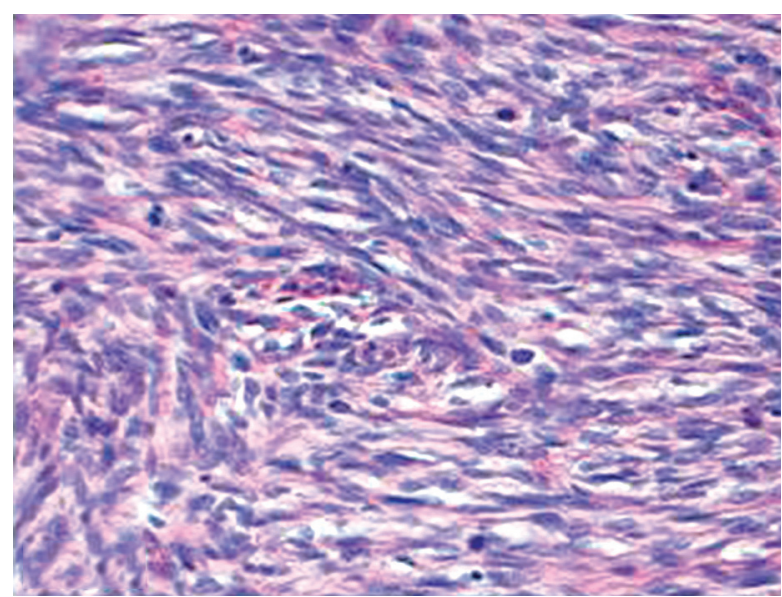

Figure I. Histopathological findings. Spindle cell proliferation. The presence of mitotic figures

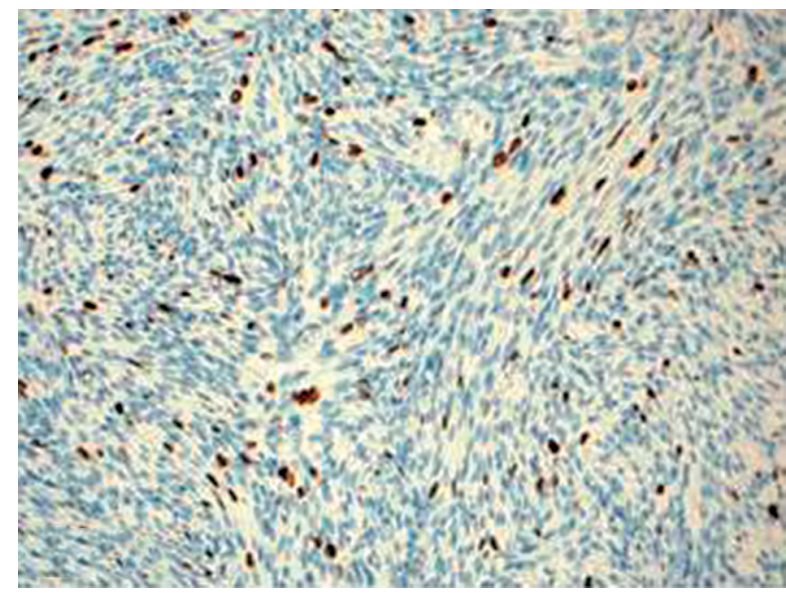

Figure 2. Immunohistochemical findings. Evaluation of Ki67 dency for infiltrative growth. The most common location is the trunk (47\%), followed by the lower limb $(20 \%)$, upper limb (18\%) and finally the head and neck $(14 \%)$. The most common clinical problem is its local recurrence. Metastases are rare (1-4\%) and usually occur late in the disease [1]. In the literature to date, only a few cases of imatinib application in patients with fibrosarcoma have been described $[2,3]$.

\section{OBJECTIVE}

In this study we describe a case of DFSP in the area of the shoulder joint.

\section{CASE REPORT}

A 62-year-old woman was admitted to the emergency department due to a growing, easily bleeding tumor of the left shoulder. Physical examination revealed the presence of an extensive, infiltrative lesion in the shoulder girdle area, on the left side. The tumor ranged from the sternum across the shoulder joint, and on the back to the edge of the scapula. Its lower edge covered one-third of the left upper arm. The central part of the lesion took the form of an exophytic,

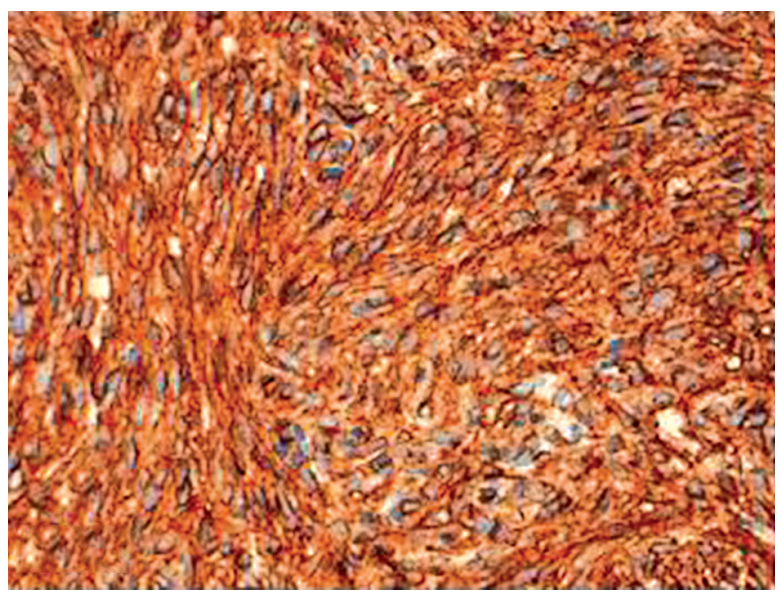

Figure 3. Immunohistochemical findings. Expression of CD34 


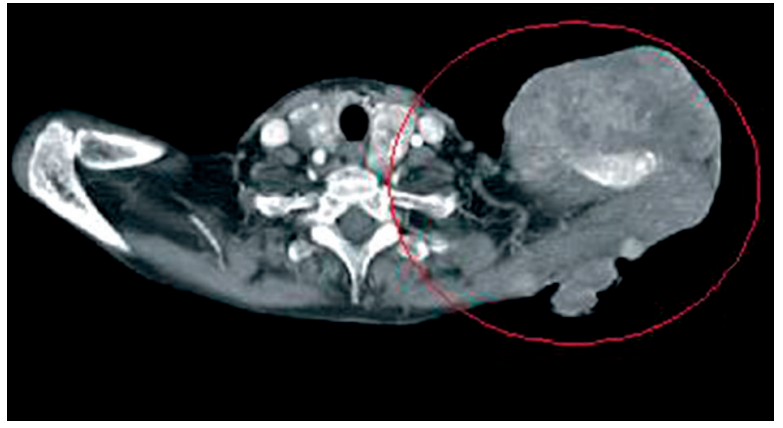

Figure 4. CT scan of the left shoulder joint area visualized the presence of a vast polycyclic mass, considerably convex toward the rostral part, with approximate size about $12 \mathrm{~cm} \times 10 \mathrm{~cm} \times 7.3 \mathrm{~cm}$

bleeding tumor, with the size of $30 \mathrm{~cm} \times 25 \mathrm{~cm}$. The lesion had begun to develop in the area of the shoulder about 5 years ago. At first it was about $2 \mathrm{~cm}$ in diameter. On admission, the patient underwent surgical consultation and was not qualified for a radical operation because of the severity of the disease. A decision to collect material for histopathological examination was made. On the basis of histopathological and immunohistochemical evaluation of the sampled material, dermatofibrosarcoma protuberans was diagnosed (Figs. 1-3).

The patient was referred to the Cancer Centre Institute in Gliwice, in order to qualify her for molecularly targeted therapy. X-ray of the chest and abdominal ultrasound showed no metastatic disease. Computed tomography (CT) scan of the left shoulder joint area visualized the presence of a vast polycyclic mass, considerably convex toward the rostral part, with an approximate size about $12 \mathrm{~cm} \times 10 \mathrm{~cm}$ $\times 7.3 \mathrm{~cm}$ (Fig. 4). At the front and at the top the lesions adhered to the shoulder muscle and at the bottom covered the skin in the area of the scapula and subcutaneous tissue.

The patient met the criteria for inclusion in treatment with imatinib, as part of the National Health Fund. In the assessment of treatment effect after 3 cycles, in a physical examination and imaging studies partial regression of the lesions above 50\% (decrease in lesion size to the dimensions of $7.9 \mathrm{~cm} \times$ $5.8 \mathrm{~cm} \times 3.2 \mathrm{~cm}$ ) was observed. In subsequent studies further regression of lesions was observed. After the sixth cycle of treatment an increase of transaminase and bilirubin levels was observed. Because of the hepatological side effects (a 5-fold increase of transaminases) the treatment was discontinued. After the normalization of transaminase levels, treatment was continued but with a dose reduced to $400 \mathrm{mg}$ of imatinib per day. Further tolerability was good. Currently, physical examination of the shoulder girdle area, on the left side, shows that the lesion covers the shoulder joint and has dimensions of $6 \mathrm{~cm} \times$

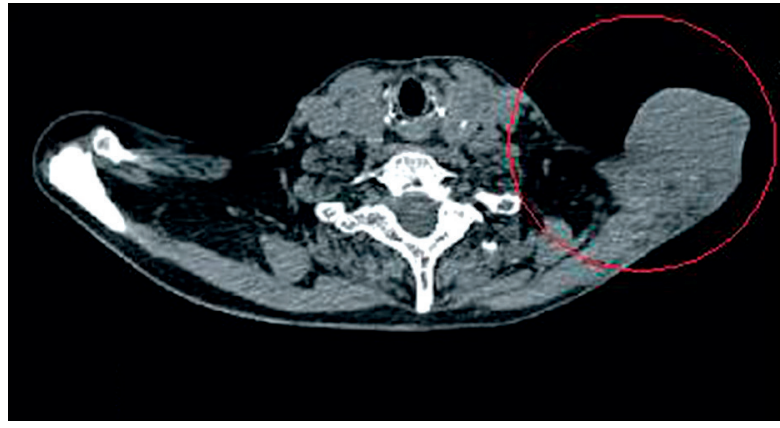

Figure 5. CT scan of the left shoulder joint area visualized partial regression of the lesions above $50 \%$ (decrease in lesion size to the dimensions of $5.8 \mathrm{~cm} \times 3.2 \mathrm{~cm}$ )

$5.5 \mathrm{~cm}$. In a CT scan of the left shoulder joint area, which was made in July 2013, further regression in tumor size was documented (Fig. 5). The tumor does not cause obvious characteristics of bone destruction. The patient has regained considerable mobility of the shoulder joint. An improvement of quality of life and the ability to function independently has been achieved. Even after achieving partial regression, surgery could lead to significant deterioration of upper limb function. The patient decided against an operation. A decision to continue the treatment has been made.

\section{DISCUSSION}

Dermatofibrosarcoma protuberans is a tumor with a low degree of differentiation, characterized by a high incidence of recurrence. The primary treatment for DFSP is surgical removal of the lesion. Radiation therapy and chemotherapy are much less effective [4, 5]. An excision with a sufficiently large margin $(5 \mathrm{~cm})$ reduces recurrence of the disease [6]. For many years, the presence of unresectable changes posed a major therapeutic problem. Introduction of molecular targeted therapy to the treatment of DFSP, such as imatinib, improved efficacy of treatment in this group of patients. Imatinib is a tyrosine kinase inhibitor that has been registered for treatment of adult patients with inoperative and recurrent or metastatic DFSP, which are not suitable for surgery. In some studies it was confirmed that therapy with imatinib may significantly reduce the tumor volume and enable radical surgery $[2,7]$.

In more than $90 \%$ of DFSP cases a supernumerary ring chromosome or a chromosomal unique translocation 17 and $22 \mathrm{t}(17 ; 22)(22 ; \mathrm{q} 13)$ is detected. The translocation leads to creation of a fusion oncogene without regulation of the expression and fully functional PDGFB. Consequently, activation of plateletderived growth factor receptors (PDGFR) and then continuous stimulation of the growth of tumor cells occur. Imatinib is a strong inhibitor of PDGFR $[8,9]$. 
The effectiveness of imatinib in the treatment of DFSP was confirmed in multi-center phase II clinical trials, such as the EORTC 62027, SWOG 0345 and DeCOG. These studies evaluated the efficacy and safety of imatinib treatment in patients with advanced or metastatic DFSP and the possibility of neoadjuvant treatment in order to limit the extent of the operation. The clinical benefit of treatment was achieved in $70.9 \%$ of patients (including partial remission in $46 \%$ of patients), the median time to disease progression was 1.7 years, and progression-free survival from the disease was $60 \%$. A median overall survival was not reached. Translocation (17:22) [(q22:q13)] or its gene product was present in almost all patients who responded to treatment with imatinib [9-12].

\section{CONCLUSIONS}

The use of imatinib allowed us to gain a clinical benefit in the form of significant regression of lesions. A very good treatment response and significant improvement in quality of life of the patient were achieved. A dose reduction allowed us to continue treatment with very good tolerability. The patient has been treated with imatinib for 30 months.

\section{ACKNOWLEDGMENTS}

I would like to express my very great appreciation to Dr Bogna Szczęśniak-Kłusek for photographs of histopathological findings.

\section{References}

1. Bogucki B., Neuhaus L., Hurst E.A.: Dermatofibrosarcoma protuberans: a review of the literature. Dermatol Surg 2012, 38, 537-551.

2. Wicherts D.A., Coevorden F., Klomp H.M., Huizum M.A., Kerst J.M., Haas R.L.M., et al.: Complete resection of recur-

\footnotetext{
Otrzymano: $\quad 22$ II 2014 r.

Zaakceptowano: 5 V 2014 r.
}

rent and initially unresectable dermatofibrosarcoma protuberans downsized by Imatinib. World J Surg Oncol 2013, 11, 59.

3. Lemm D., Muegge L.O., Hoeffken K., Aklan T., Mentzel T., Thorwarth M., et al.: Remission with Imatinib mesylate treatment in a patient with initially unresectable dermatofibrosarcoma protuberans - a case report. Oral Maxillofac Surg 2008, 12, 209-213.

4. Lemm D., Mügge L.O., Mentzel T., Höffken K.: Current treatment options in dermatofibrosarcoma protuberans. J Cancer Res Clin 2009, 135, 653-665.

5. Llombart B., Serra-Guillèn C., Monteagudo C., López Guerrero J.A., Sanmartin O.: Dermatofibrosarcoma protuberans: a comprehensive review and update on diagnosis and management. Semin Diagn Pathol 2013, 30, 13-28.

6. D'Andrea F., Vozza A., Brongo S., Di Girolamo F., Vozza G.: Dermatofibrosarcoma protuberans: experience with 14 cases. JEADV 2001, 15, 427-429.

7. Rutkowski P., Dębiec-Rychter M., Nowecki Z.I., MichejW., Symonides M., Ptaszynski K., et al.: Treatment of advanced dermatofibrosarcoma protuberans with imatinib mesylate with or without surgical resection. JEADV 2011, 25, 264-270.

8. Sjöblom T., Shimizu A., O'Brien K.P., Pietras K., Dal Cin P., Buchdunger E., et al.: Growth inhibition of dermatofibrosarcoma protuberans tumors by the platelet-derived growth factor receptor antagonist STI571 through induction of apoptosis. Cancer Res 2001, 61, 5778-5783.

9. Wang J., Morimitsu Y., Okamoto S., Hisaoka M., Ishida T., Sheng W., et al.: COL1A1-PDGFB fusion transcript in fibrosarcomatous areas of six dermatofibrosarcoma protuberans. J Mol Diagn 2000, 2, 47-52.

10. Rutkowski P., Van Glabbeke M., Rankin C.J., Ruka W., Rubin B.P., Debiec-Rychter M., et al.: Imatinib mesylate in advanced dermatofibrosarcoma protuberans (DFSP): pooled analysis of two phase II clinical trials J Clin Oncol 2010, 28, 1772-1779.

11. Heinrich M.C., Joensuu H., Demerti G.D., Corless C.L., Apperley J., Fletcher J.A., et al.: Phase II, open-label study evaluating the activity of imatinib in treating life-threatening malignancies known to be associated with imatinib-sensitive tyrosine kinases. Clin Cancer Res 2008, 14, 2717-2725.

12. Ugurel S., Mentzel T., Utikal J., Helmbold P., Mohr P., Pföhler C., et al.: Neoadjuvant imatinib in advanced primary or locally recurrent dermatofibrosarcoma protuberans: a multicenter phase II DeCOG trial with long-term followup. Clin Cancer Res 2014, 15, 499-510. 